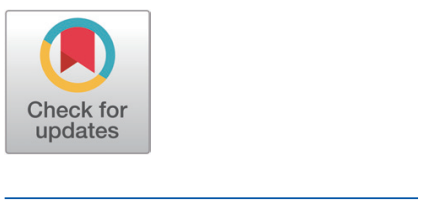

Received: Aug 19, 2020

Revised: Oct 13, 2020

Accepted: Dec 7, 2020

*Corresponding author

Hack-Youn Kim

Department of Animal Resources

Science, Kongju National University,

Yesan 32439, Korea

Tel: +82-41-330-1241

E-mail: kimhy@kongju.ac.kr

Copyright $\odot 2021$ Korean Society of Animal Sciences and Technology. This is an Open Access article distributed under the terms of the Creative Commons Attribution Non-Commercial License (http:// creativecommons.org/licenses/bync/4.0/) which permits unrestricted non-commercial use, distribution, and reproduction in any medium, provided the original work is properly cited.

ORCID

Kyu-Min Kang

https://orcid.org/0000-0002-4904-1976 Sol-Hee Lee

https://orcid.org/0000-0003-1124-7095

Hack-Youn Kim

https://orcid.org/0000-0001-5303-4595

Competing interests

No potential conflict of interest relevant to this article was reported.

Funding sources

This work was carried out with the support of "Cooperative Research Program for Agriculture Science \& Technology Development (Project No.PJ01528103)" Rural Development Administration, Korea.

Acknowledgements Not applicable.

Availability of data and material Upon reasonable request, the datasets

\section{Quality properties of whole milk powder on chicken breast emulsion-type sausage}

\author{
Kyu-Min Kang, Sol-Hee Lee and Hack-Youn Kim* \\ Department of Animal Resources Science, Kongju National University, Yesan 32439, Korea
}

\begin{abstract}
The aim of the study was to determine the effect of whole milk powder (WMP) as heterologous proteins on chicken breast emulsion-type sausages. The quality properties of WMP on such chicken breast emulsion-type sausages were investigated by measuring the proximate composition, $\mathrm{pH}$, color, cooking yield, protein solubility, and by applying other methods, such as texture profile analysis (TPA), microphotograph, sodium dodecyl sulfate-polyacrylamide gel electrophoresis (SDS-PAGE), and electronic nose. The crude fat, protein, and ash contents of $15 \%$ WMP samples were significantly higher than the control samples $(p<0.05)$. The redness of the cooked samples significantly increased with an increase in the WMP contents $(p<0.05)$. The cooking yield of WMP treated samples was significantly higher than the control sample $(p<0.05)$. Additionally, the hardness, gumminess, and chewiness of WMP treated samples were significantly higher than the control sample $(p<0.05)$. The sarcoplasmic and myofibrillar proteins of samples containing $15 \%$ WMP were significantly higher than the control samples $(p<0.05)$. The result of SDS-PAGE showed that the $C$ protein, sarcoplasmic protein, actin, and tropomyosin increased with an increase in the WMP contents. The principal component analysis plot of WMP-treated samples was clearly different from that of the control samples. Based on these results, it was predicted that WMP could be useful as heterologous protein on emulsion-type sausage.
\end{abstract}

Keywords: Chicken, Heterologous-protein, Quality, Sausage, Milk

\section{INTRODUCTION}

Consumer demands for convenient home meal replacements, such as instant foods have been increased rapidly with an increase in the number of smaller household sizes in recent years [1]. In addition, as food culture has become more westernized, consumers have greater demand for processed meat products, such as, ham, fish cake bar, and sausage. These products account for a larger percentage of the home meal replacement market than the other instant foods [2].

Sausages are one of the most popular processed meat products, usually made from pork or chicken. Most consumers prefer chicken based sausages over beef or pork due to the nutritional values of the former, which includes high protein, low fat and cholesterol contents as well as low calories [3]. In 2007, the annual chicken consumption per capita was $13.3 \mathrm{~kg}$. This number increased by $11 \%$ over the last two years and reached $14.8 \mathrm{~kg}$ in 2019, potentially due to the availability of a greater variety of products 
of this study can be available from the corresponding author.

Authors' contributions

Conceptualization: Kang KM, Kim HY.

Data curation: Kang KM, Lee SH.

Formal analysis: Kang KM.

Methodology: Kang KM.

Software: Lee SH.

Validation: Lee SH.

Investigation: Kang KM, Lee SH.

Writing - original draft: Kang KM.

Writing - review \& editing: Kim HY.

Ethics approval and consent to participate This article does not require IRB/IACUC approval because there are no human and animal participants. containing chicken [4]. Several studies have been conducted out to improve the quality of chicken sausages $[5,6]$. For example, studies have shown that during production, the emulsifying capacity is improved with higher protein content. Thus, sausage production companies use additional heterologous proteins, such as isolated soy protein, concentrated soy protein and milk powder $[7,8]$.

Milk powder is an animal protein and is classified into four types: whole milk powder (WMP), skimmed milk powder, sweetened milk powder, and mixed milk powder. Among these, WMP has high protein and fat contents, as it is a powdered form of raw milk produced through a drying process that removes water to a moisture content below 5.0\%; this preserves the composition of the raw milk and to increases its shelf life [9]. Kamizake et al. [10] reported that cream, mayonnaise, imitation milk, and sausage containing WMP were rich in casein protein that enhances their emulsifying capacity. Similarly, there are many studies that have explored the use of WMP as the main food additive in semi-solid products such as cheese, yogurt and soup [11-13]. However, only a few studies have used WMP as a heterologous protein and evaluated its use as a functional additive, such as an emulsifier.

Therefore, this study has examined the effect of using WMP as a heterologous protein in chicken breast emulsion-type sausages. Furthermore, the quality properties were compared and analyzed to determine the optimal additive ratio.

\section{MATERIALS AND METHODS}

\section{Preparation of whole milk powder on chicken emulsion sausage}

Chicken breast (12 h after slaughter from, Maniker, Seoul, Korea) was used for chicken emulsiontype sausage for this study. The chicken breast and pork back fat were ground using grinder (PA82, Mainca, Barcelona, Spain) with $3 \mathrm{~mm}$ plate; the primary materials as chicken breast (60\%), pork back fat (20\%), and ice (20\%), were then emulsified using a bowl cutter (K-30, Talsa, Valencia, Spain). After the emulsification, nitrite pickling salt (1.2\%), sugar (1\%), mixed spices (1\%) were added. Then three samples were prepared by adding 5\%,10\%, and 15\% WMP. The prepared samples emulsion was filled in a natural pork intestine casing using a stuffer (EM-12, Mainca), and cooked for 40 min at $80^{\circ} \mathrm{C}$ chamber (10.10ESI/SK, Alto Shaam, Menomonee Falls, WI, USA). After cooking, it was cooled at $10^{\circ} \mathrm{C}$ for $20 \mathrm{~min}$.

$\mathrm{pH}$

Each sample $(4 \mathrm{~g})$ was mixed with distilled water $(16 \mathrm{~mL})$ using Ultra Turrax homogenizer (HMZ-20DN, Pooglim Tech, Seongnam, Korea) for $1 \mathrm{~min}$ at 6,991×g, and was measured using a glass electrode pH meter (Model S220, Mettler-Toledo, Schwerzenbach, Switzerland).

\section{Color}

The color of chicken emulsion-type sausages were measured before and after cooking, using a colorimeter (CR-10, Minolta, Tokyo, Japan, calibrated with a white plate, CIE L*: +97.83, CIE a*: -0.43 , and CIE $\left.b^{*}:+1.98\right)$. The measured color value was recorded as CIE $L^{*}, C I E ~ a *$ and CIE $b^{*}$.

\section{Proximate composition}

Proximate composition of the samples was determined following the AOAC guidelines [14]. The moisture content, crude protein, crude fat, and crude ash content were determined by drying oven method at $105^{\circ} \mathrm{C}$, Kjeldahal method, Soxhlet method, and dry ashing method at $550^{\circ} \mathrm{C}$, respectively. 


\section{Sodium dodecyl sulfate-polyacrylamide gel electrophoresis (SDS-PAGE)}

Relevant protein levels were assessed with SDS-PAGE analysis, using 8\% separating gel and 4\% stacking gel, following the method described by Lee et al. [15]. The supernatants of the samples were mixed with $3 \mathrm{mM}$ phosphate buffer and $5 \mathrm{X}$ sample buffer. Each sample $(15 \mu \mathrm{L})$ was added to the gel and processed for $120 \mathrm{~min}$. After the process, gel was $12 \mathrm{~h}$ overnight in a fixing solution using a rocker, and stained with Coomassie brilliant blue for $20 \mathrm{~min}$ with gentle agitation. The dye was removed by incubation in a de-staining solution for $1 \mathrm{~h}$, and the gel was stored in a storage solution and scanned.

\section{Protein solubility}

Protein solubility of samples was determined using the method from Kang et al. [6]. The total protein solubility was determined with mixing $2 \mathrm{~g}$ of sample with $20 \mathrm{~mL}$ of buffer $(1.1 \mathrm{M}$ potassium iodide in $0.1 \mathrm{M}$ potassium phosphate buffer). However, the sarcoplasmic protein solubility was determined by mixing $2 \mathrm{~g}$ of the sample with $20 \mathrm{~mL}$ buffer $(0.025 \mathrm{M}$ potassium phosphate). Each sample were homogenized using homogenizer (AM-5, Nihonseiki, Tokyo, Japan) at 3,932×g for $2 \mathrm{~min}$. After homogenized, the samples were kept at $4^{\circ} \mathrm{C}$ for $16 \mathrm{~h}$ and filtered filter paper. The sample supernatant was measured at absorbance of $540 \mathrm{~nm}$ on the multi-mode microplate reader (Spectra Max iD3, Molecular devices, San Jose, CA, USA). Myofibrillar protein solubility was calculated by the difference between total and sarcoplasmic protein solubility.

\section{Scanning microphotograph}

The samples were stored at $-80^{\circ} \mathrm{C}$ for $24 \mathrm{~h}$ deep freezer (TSE320GPD, Thermo Fisher Scientific, Waltham, MA, USA), and sliced into $10 \mu \mathrm{m}$ sections using a cryostat (CM3050S, Leica Biosystems, Wetzlar, Germany). The sliced samples were observed and scanned using upright clinical microscope (Eclipse Ci-L, Nikon, Tokyo, Japan).

\section{Cooking yield}

The samples were weighed before and after cooking. The cooking yield was determined from their weights and calculated (1).

$$
\text { Cooking yield }(\%)=\frac{\text { Sample weight a fter cooking }(\mathrm{g})}{\text { Sample weight before cooking }(\mathrm{g})} \times 100
$$

\section{Texture profile analysis (TPA)}

The cooked samples were cut into $\$ 2.5 \times 2.0 \mathrm{~cm}$ (diameter $\times$ height) sections. The texture was measured using a texture analyzer (TA 1, Lloyd, Largo, FL, USA), and the analyzing conditions were: cylinder probe of $100 \mathrm{~mm}$ diameter with a pre-test speed of $2.0 \mathrm{~mm} / \mathrm{s}$, a post-test speed of $5.0 \mathrm{~mm} / \mathrm{s}$, a maximum load of $2 \mathrm{~kg}$, a head speed of $2.0 \mathrm{~mm} / \mathrm{s}$, a distance of $8.0 \mathrm{~mm}$, and a force of $5 \mathrm{~g}$. Hardness (kg), springiness, and cohesiveness were measured and recorded, which were used for calculating gumminess $(\mathrm{kg})$ and chewiness $(\mathrm{kg})$.

\section{Aroma characterization}

Aroma profiling of the cooked chicken emulsion-type sausage samples were performed using a Heracles II electronic nose (Alpha MOS, Toulouse, France); the conditions for analysis were: $5 \mathrm{~g}$ of sample was weighed in a $20 \mathrm{~mL}$ vial; flow rate of $250 \mathrm{~mL} / \mathrm{min}$; acquisition time of $120 \mathrm{~s}$; headspace temperature of $60^{\circ} \mathrm{C}$; an injection of $2.5 \mathrm{~mL}$ of sample. The measured sensitivity values were used in the Alpha soft program (Alpha MOS), used for the PCA procedure. The classified aroma pattern 
was recorded as the primary component value (PC1) and the secondary component value (PC2).

\section{Statistical analysis}

Experimental results were assessed after at least three repeated trials. Statistical analyses were performed using SAS version 9.3 for window (SAS Institute, Cary, NC, USA), and the results were indicated as mean \pm and standard deviation. ANOVA and Duncan's multiple range test were performed for verifying the significance of differences among the averages of each characteristic.

\section{RESULTS AND DISCUSSION}

\section{$\mathrm{pH}$ and color}

Table 1 shows the results of $\mathrm{pH}$ and color analysis for uncooked and cooked sausages containing different amounts of WMP. $\mathrm{pH}$ is a measurement that determines the quality of meat and meat products; a high $\mathrm{pH}$ value of an emulsified sausages enhance its water-holding capacity [16]. The $\mathrm{pH}$ analysis results revealed that, before cooking, the $\mathrm{pH}$ significantly increased with an increase in the total WMP $(p<0.05)$. Akhtar et al. [17] noted that WMP has a high $\mathrm{pH}$ value of 6.73 , and this suggested that the observed increase in $\mathrm{pH}$, which was higher than the control samples, was due to adding WMP. Similarly, a study by Eswarapragada et al. [18] on pork sausage containing milk co-precipitate reported that the $\mathrm{pH}$ of sausage increased with an increase in the amount of milk co-precipitate added.

Color measurement results revealed that the lightness before cooking increased with an increase in WMP added; the lightness of after cooking also showed significantly higher values in sausages containing WMP than in the control sample $(p<0.05)$. A previous study reported that WMP has a lightness range of $75-85$, which is higher than the lightness of typical emulsified sausages without added WMP [19]. Andrès et al. [20] demonstrated that chicken sausages containing whey protein, extracted from milk, also showed an increase in lightness as the added amount of whey protein increased. The redness of uncooked sausages was significantly lower in the 5\% WMPtreated sample compared to the control sample and the 15\% WMP-treated sample $(p<0.05)$, but a consistent trend regarding WMP added was not observed. However, the CIE $\mathrm{a}^{*}$ value in cooked

Table 1. pH and color of chicken-breast emulsion-type sausage formulated with various levels of whole milk powder

\begin{tabular}{|c|c|c|c|c|}
\hline \multirow{2}{*}{ Traits } & \multirow{2}{*}{ Control } & \multicolumn{3}{|c|}{ Whole milk powder (\%) } \\
\hline & & 5 & 10 & 15 \\
\hline \multicolumn{5}{|l|}{$\mathrm{pH}$} \\
\hline Uncooked & $5.86 \pm 0.03^{d}$ & $5.97 \pm 0.02^{c}$ & $6.07 \pm 0.02^{b}$ & $6.11 \pm 0.01^{\mathrm{a}}$ \\
\hline Cooked & $6.07 \pm 0.01^{\mathrm{c}}$ & $6.11 \pm 0.02^{b}$ & $6.16 \pm 0.01^{\mathrm{a}}$ & $6.17 \pm 0.01^{\mathrm{a}}$ \\
\hline \multicolumn{5}{|l|}{ Color } \\
\hline \multicolumn{5}{|l|}{ Uncooked } \\
\hline $\mathrm{CIE} \mathrm{L*}$ & $66.12 \pm 0.29^{b}$ & $72.67 \pm 2.09^{\mathrm{ab}}$ & $75.15 \pm 0.15^{\mathrm{a}}$ & $75.05 \pm 0.12^{\mathrm{a}}$ \\
\hline CIE $a^{*}$ & $7.86 \pm 0.12^{\mathrm{a}}$ & $6.76 \pm 0.27^{b}$ & $7.20 \pm 0.30^{\mathrm{ab}}$ & $7.70 \pm 0.10^{\mathrm{a}}$ \\
\hline $\mathrm{CIE} b^{*}$ & $19.95 \pm 0.65$ & $19.90 \pm 0.60$ & $21.35 \pm 0.45$ & $21.80 \pm 0.50$ \\
\hline \multicolumn{5}{|l|}{ Cooked } \\
\hline $\mathrm{CIE} \mathrm{L}^{*}$ & $73.14 \pm 0.15^{b}$ & $76.70 \pm 0.12^{a}$ & $77.40 \pm 0.10^{\mathrm{a}}$ & $78.47 \pm 0.62^{a}$ \\
\hline $\mathrm{CIE} \mathrm{a}^{*}$ & $6.00 \pm 0.12^{d}$ & $6.73 \pm 0.03^{c}$ & $7.13 \pm 0.03^{b}$ & $7.60 \pm 0.16^{a}$ \\
\hline CIE $b^{*}$ & $17.90 \pm 0.18^{c}$ & $18.63 \pm 0.32^{\mathrm{bc}}$ & $19.40 \pm 0.50^{\mathrm{ab}}$ & $19.77 \pm 0.07^{\mathrm{a}}$ \\
\hline
\end{tabular}

All values are mean $\pm S D$.

${ }^{a-d}$ Mean in the same row with different letters are significantly different $(p<0.05)$. 
samples significantly increased with an increase in WMP added $(p<0.05)$. Such difference in redness in the WMP-treated samples after cooking is due to the oxidation of lactose and casein protein in the WMP during its freezing process of sausages [21], as these substances undergo the Maillard reaction when they are in contact with oxygen [22]. Therefore, a consistent change in redness regarding the addition of WMP was not observed in uncooked samples, whereas an increase in redness was seen in cooked samples. Before cooking, the CIE $b^{*}$ value did not show significant difference between the control and WMP-treated samples; however, in cooked samples, it was significantly higher in $10 \%$ and 15\% WMP-treated samples than in the control sample $(p<0.05)$. In a study on the browning of casein protein, Morales and Boekel [23] reported that application of heat to casein protein led to an increase in yellowness due to the Maillard reaction, and it is believed that the results followed this phenomenon.

\section{Proximate composition and sodium dodecyl sulfate-polyacrylamide gel electro- phoresis (SDS-PAGE)}

The proximate composition of chicken breast emulsion-type sausage containing WMP is presented in Table 2. The moisture content showed a decreasing trend with adding an increasing amount of WMP. However, the crude fat and protein contents tended to increased, especially the crude ash content showed a significant increase as WMP added increased $(p<0.05)$. The proximate composition of WMP is $3.3 \%$ moisture, $26.8 \%$ crude fat, $41.7 \%$ protein, and $4.1 \%$ crude ash [24], and it was understood that a difference in the proximate compositions among the WMPtreated samples occurred because of the varying amounts of WMP added. Further, whey protein concentrate indicated that the protein content increased with an increase in the added amount of milk-derived protein, similar to reports by Hung and Zayas [25] on meat products containing skimmed milk and whey protein, and by Abdolghafour and Saghir [26] on buffalo meat emulsion sausage containing.

The SDS-PAGE analysis of chicken breast sausage with added WMP is shown in Fig. 1. The content of proteins, such as $\mathrm{C}$ protein, actin, sarcoplasmic protein, and tropomyosin, increased with an increase in the amount of added WMP. Radoslav and Danica [27] stated that the molecular weight of enolase belonging to the sarcoplasmic protein is $53.82 \pm 1.42 \mathrm{kDa}$. This experiment also showed similar results in which the sarcoplasmic protein content increased, which resulted from an increase in the protein solubility the increased due to the increased addition of WMP. Furthermore, tropomyosin plays the role of improving protein solubility, and this experiment also showed that the tropomyosin content increased with an increase in the WMP content; which is one of the reasons for the increase in protein solubility observed in this study [28]. In addition, considering that C protein known as a blood coagulation inhibitor that prevents vascular diseases [29], and its content increases with an increase in the amounts of WMP additive, adding WMP may aid in creating

Table 2. Proximate composition of chicken-breast emulsion-type sausage formulated with various levels of whole milk powder

\begin{tabular}{lcccc}
\hline \multirow{2}{*}{ Traits } & \multirow{2}{*}{ Control } & \multicolumn{3}{c}{ Whole milk powder (\%) } \\
\cline { 3 - 5 } & & $\mathbf{5}$ & $\mathbf{1 0}$ & $\mathbf{1 5}$ \\
\hline Moisture & $58.36 \pm 1.08^{\mathrm{a}}$ & $57.35 \pm 0.49^{\mathrm{ab}}$ & $55.56 \pm 0.32^{\mathrm{b}}$ & $52.24 \pm 0.17^{\mathrm{c}}$ \\
Crude fat & $19.97 \pm 0.05^{\mathrm{c}}$ & $19.80 \pm 0.09^{\mathrm{c}}$ & $20.24 \pm 0.07^{\mathrm{b}}$ & $20.56 \pm 0.05^{\mathrm{a}}$ \\
Crude protein & $17.86 \pm 0.21^{\mathrm{c}}$ & $18.85 \pm 0.09^{\mathrm{b}}$ & $19.30 \pm 0.24^{\mathrm{ab}}$ & $19.69 \pm 0.24^{\mathrm{a}}$ \\
Crude ash & $2.35 \pm 0.02^{\mathrm{d}}$ & $2.57 \pm 0.01^{\mathrm{c}}$ & $2.71 \pm 0.02^{\mathrm{b}}$ & $2.82 \pm 0.04^{\mathrm{a}}$ \\
\hline
\end{tabular}

All values are mean $\pm S D$.

${ }^{a-d}$ Mean in the same row with different letters are significantly different $(p<0.05)$. 


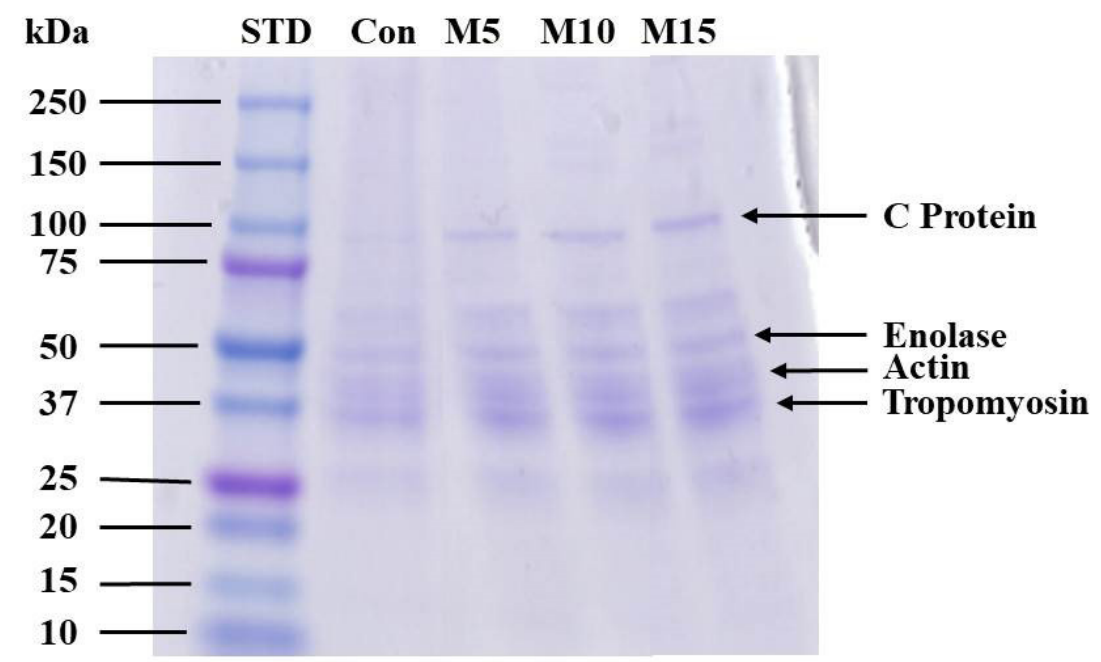

Fig. 1. SDS-PAGE of chicken-breast emulsion-type sausage formulated with various levels of whole milk powder. STD, standard; Con, control; M5, sausage added $5 \%$ of whole milk powder; M10, sausage added $10 \%$ of whole milk powder; M15, sausage added $15 \%$ of whole milk powder; SDS-PAGE, sodium dodecyl sulfatepolyacrylamide gel electrophoresis.

products with added functionalities and benefits. From the SDS-PAGE results, it was concluded that adding WMP increased the protein content, which had a beneficial effect on the processing quality and improved the protein solubility and physical properties, not only facilitating a stable sausage production but also a high protein product.

\section{Protein solubility, scanning microphotograph, and cooking yields}

Protein solubility is greatly affected by its molecular weight as well as the structure and function of the added protein [30]. As such, the results of protein solubility of chicken breast sausage containing WMP are summarized in Table 3. The total protein content in WMP-treated samples showed significantly higher values than that of the control sample $(p<0.05)$. The sarcoplasmic protein content was significantly higher in the 15\% WMP-treated sample than in the control sample $(p$ $<0.05$ ), and the myofibrillar protein content was significantly higher in the 10\% and 15\% WMPtreated samples than in the control sample $(p<0.05)$. All experimental groups showed an overall increase in protein solubility with an increasing amount of WMP added. A study by Agarwal et al. [31] reported that the protein solubility of milk protein also increases with an increasing $\mathrm{pH}$. Similar results were obtained in this study, where an increasing added amount of WMP in the WMP-treated samples resulted in an increase of $\mathrm{pH}$ increasing the solubility.

Table 3. Protein Solubility of chicken-breast emulsion-type sausage formulated with various levels of whole milk powder

\begin{tabular}{lrrrr}
\hline \multirow{2}{*}{ Traits $(\mathbf{m g} / \mathbf{g})$} & \multirow{2}{*}{ Control } & \multicolumn{3}{c}{ Whole milk powder (\%) } \\
\cline { 3 - 5 } & & $\mathbf{5}$ & $\mathbf{1 0}$ & 15 \\
\hline Total protein solubility & $114.3 \pm 2.45^{\mathrm{c}}$ & $137.6 \pm 2.45^{\mathrm{b}}$ & $140.2 \pm 12.24^{\mathrm{ab}}$ & $157.1 \pm 0.61^{\mathrm{a}}$ \\
Sarcoplasmic protein solubility & $103.0 \pm 6.12^{\mathrm{b}}$ & $108.2 \pm 2.45^{\mathrm{ab}}$ & $109.5 \pm 3.06^{\mathrm{ab}}$ & $122.5 \pm 7.96^{\mathrm{a}}$ \\
Myofibrillar protein solubility & $11.3 \pm 3.67^{\mathrm{b}}$ & $29.4 \pm 4.90^{\mathrm{ab}}$ & $30.7 \pm 11.02^{\mathrm{a}}$ & $34.6 \pm 8.57^{\mathrm{a}}$ \\
\hline
\end{tabular}

All values are mean $\pm S D$.

${ }^{a-c}$ Mean in the same row with different letters are significantly different $(p<0.05)$. 
Fig. 2 shows the cross-sectional microphotographs of the chicken breast sausage with WMP additives. Generally, in emulsified meat products, the reticular structure of myosin becomes more notable as the extracted amount of salt-soluble protein increases due to the enhanced binding force between the meat proteins and fat globules, which are the main ingredients of emulsified sausages [32]; therefore, the size of fat globules decreases as the emulsification degree of emulsion-type meat products increases. This was confirmed in this study, where an increase in the WMP helped to the uniformly distribute of small fat particles. A study by Muguruma et al. [33] on chicken sausages containing soybean and casein protein demonstrated that adding casein protein improved the formation of network structures that enhanced the gel strength between tissues. This occurs as an increase in the L-lysine in casein protein induces the formation of a more compact network structure of myosin that decreases the size of fat globules and the gap within emulsified sausages [34]. Therefore, it was concluded that the emulsifying capacity increased as the milk powder added increased, since WMP can easily extract sarcoplasmic proteins by reacting with meat proteins, by performing the same function as sodium caseinate.

To achieve a high cooking yield, which is critical for emulsified products, it is important to minimize the loss of moisture and fat by enhancing the binding strength between protein and water [15]. The cooking yield of chicken breast sausage containing WMP is shown in Fig. 3. WMPtreated samples showed significantly higher values of cooking yield than the control $(p<0.05)$. Barbut [35] reported that the cooking loss in a meat product made from chicken breast added with WMP was lower than in a similar meat product without WMP; this was comparable with the experimental results demonstrated in this study. Regarding the increase in cooking yield with adding WMP, the protein has an excellent ability for retention and absorption of fat and moisture [36]; thus the cooking yield increased in this study, as the separation of moisture and fat was minimized during the cooking process. Therefore, the output of adding WMP to chicken breast
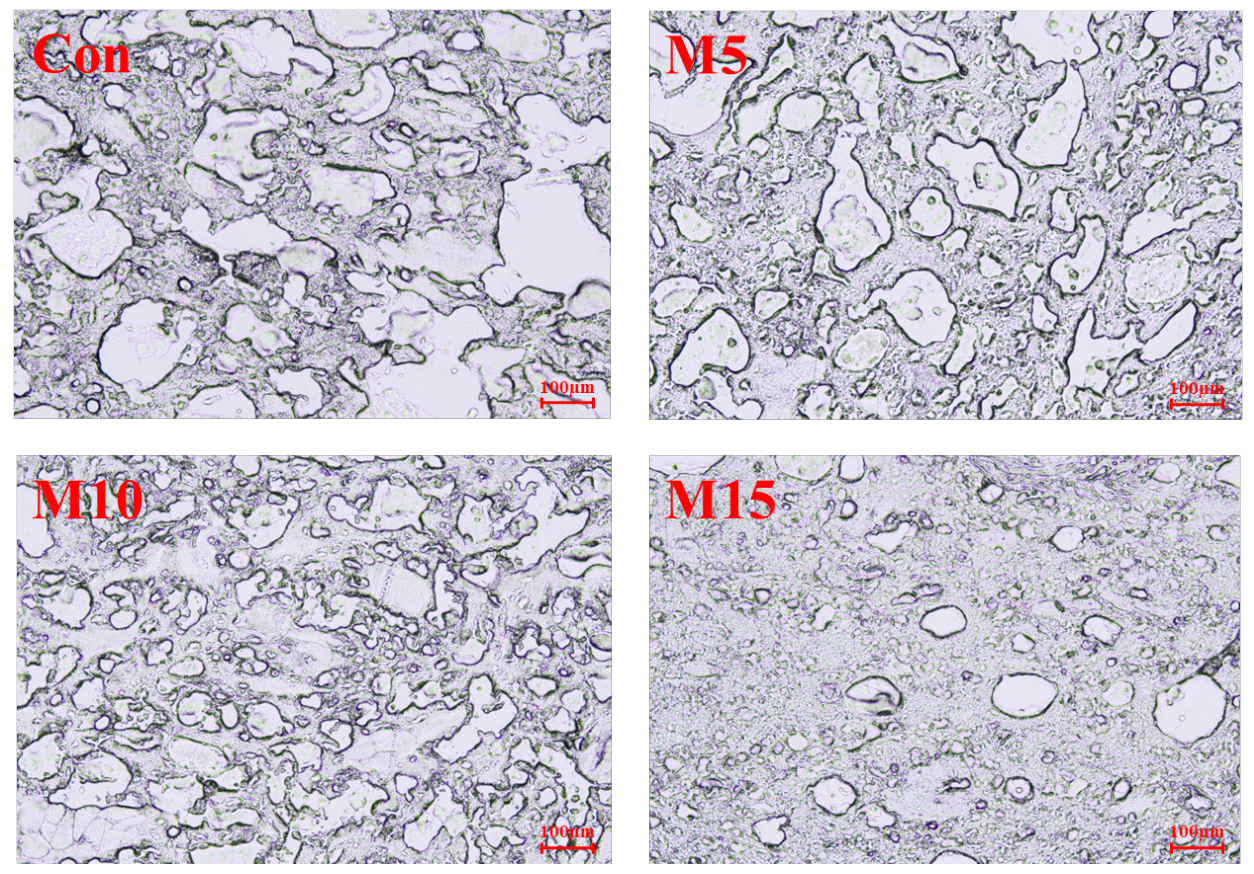

Fig. 2. Cross-sectional microphotographs of chicken-breast emulsion-type sausage formulated with various levels of whole milk powder. The magnification of all the microphotographs is $\times 40$. Con, control; $\mathrm{M}$, sausage added $5 \%$ of whole milk powder; M10, sausage added $10 \%$ of whole milk powder; M15, sausage added $15 \%$ of whole milk powder. 


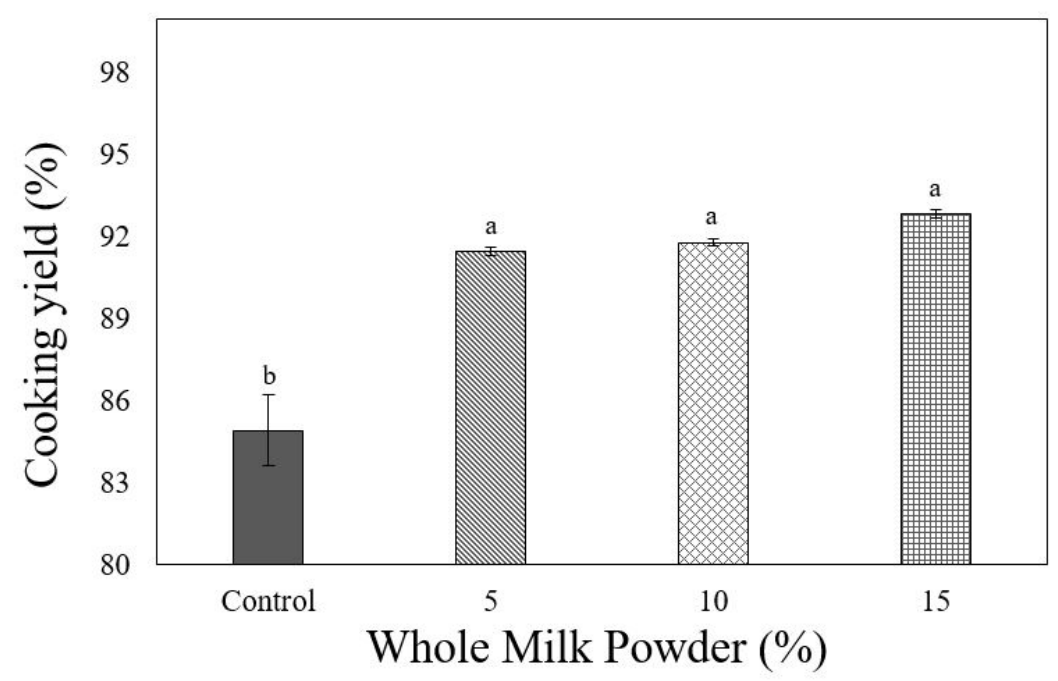

Fig. 3. Cooking yield of chicken-breast emulsion-type sausage formulated with various levels of whole milk powder. ${ }^{a, b}$ Mean in the same bars with different letters are significantly different $(p<0.05)$.

sausage is believed to be products with economically superior properties.

\section{Texture profile analysis (TPA) and electronic nose}

The TPA measurement results of chicken breast sausage formulated with different blending ratios of WMP are shown in Table 4. WMP-treated samples showed significantly higher hardness, gumminess, and chewiness values than those of the control sample $(p<0.05)$, whereas no significant difference in springiness and cohesiveness between the control group and treated samples was observed. A study by Marchetti et al. [37] showed similar results, in which addition of milk protein to low-fat sausages resulted in an increase in its hardness, gumminess, and chewiness as compared to the control sample that had no milk protein additives. This is because the WMP added during production undergoes hot air drying and remains in powder form; powders prepared under such conditions exhibit a high rehydration and emulsifying capacity [38]. Therefore, it is concluded that the increased hardness, gumminess, and chewiness can be attributed to the WMP additive that not only act as an emulsifier to improve the water retention capacity and cooking yield, but also enhances the binding strength between main and minor ingredients.

Fig. 4 shows the results of electronic nose analysis of the chicken breast sausage with added

Table 4. Texture profile analysis of chicken-breast emulsion-type sausage formulated with various levels of whole milk powder

\begin{tabular}{lcccc}
\hline \multirow{2}{*}{ Traits } & Control & \multicolumn{3}{c}{ Whole milk powder (\%) } \\
\cline { 3 - 5 } & & $\mathbf{5}$ & $\mathbf{1 0}$ & 15 \\
\hline Hardness $(\mathrm{kg})$ & $2.14 \pm 0.37^{\mathrm{c}}$ & $3.29 \pm 0.21^{\mathrm{b}}$ & $3.56 \pm 0.41^{\mathrm{ab}}$ & $3.89 \pm 0.31^{\mathrm{a}}$ \\
Springiness & $0.86 \pm 0.08$ & $0.85 \pm 0.06$ & $0.90 \pm 0.01$ & $0.89 \pm 0.04$ \\
Gumminess $(\mathrm{kg})$ & $1.51 \pm 0.17^{\mathrm{c}}$ & $2.36 \pm 0.13^{\mathrm{b}}$ & $2.62 \pm 0.25^{\mathrm{a}}$ & $2.81 \pm 0.18^{\mathrm{a}}$ \\
Chewiness $(\mathrm{kg})$ & $1.30 \pm 0.15^{\mathrm{c}}$ & $2.00 \pm 0.21^{\mathrm{b}}$ & $2.37 \pm 0.24^{\mathrm{a}}$ & $2.49 \pm 0.14^{\mathrm{a}}$ \\
Cohesiveness & $0.71 \pm 0.04$ & $0.72 \pm 0.01$ & $0.74 \pm 0.02$ & $0.72 \pm 0.01$ \\
\hline
\end{tabular}

All values are mean $\pm \mathrm{SD}$.

${ }^{a-c}$ Mean in the same row with different letters are significantly different $(p<0.05)$. 


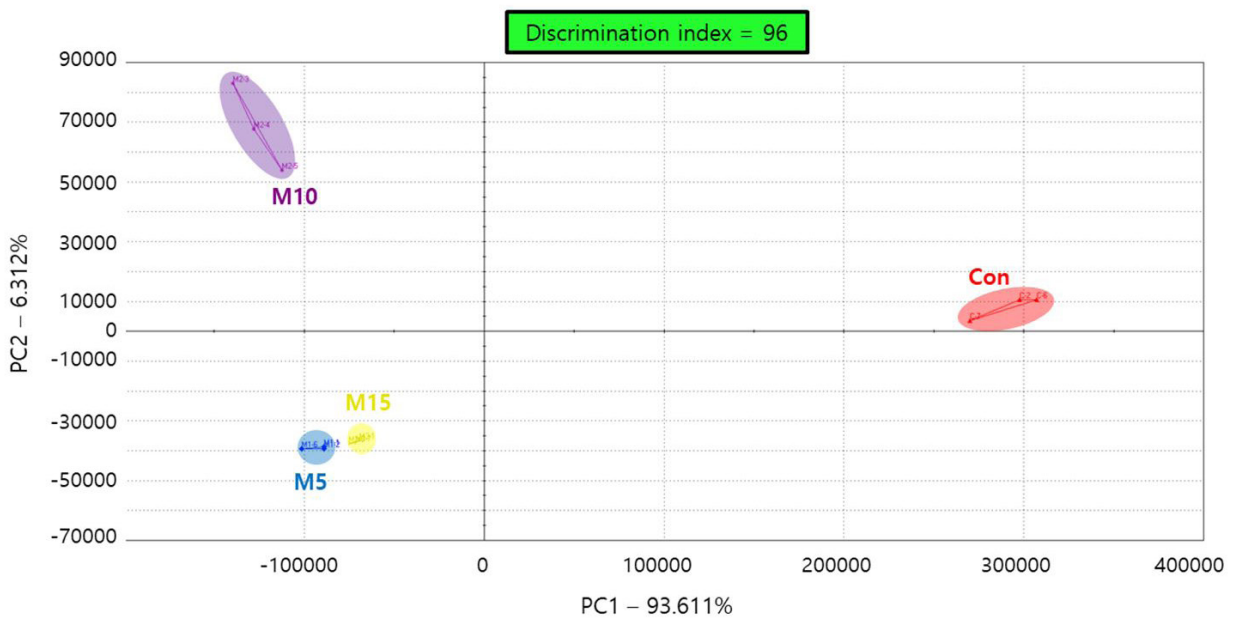

Fig. 4. Principal component analysis plot of chicken-breast emulsion-type sausage formulated with various levels of whole milk powder. Con, control; M5, sausage added $5 \%$ of whole milk powder; M10, sausage added $10 \%$ of whole milk powder; M15, sausage added $15 \%$ of whole milk powder.

WMP. The overall flavor of the protein is determined by the composition of substances that make up the protein structure, temperature, $\mathrm{pH}$, and ionic strength $[39,40]$. The PCA plot obtained in this study showed a PC1 of $93.611 \%$ and PC2 of $6.312 \%$, indicating that PC1 contributed more to enhancing the flavor [41]. Based on PC1 ( $\mathrm{x}$-axis), the PCA plot of treated samples revealed that the control and WMP-treated samples showed a difference for the major flavor component; however, there was no significant difference in the major flavor component among the WMPtreated samples. Christiansen et al. [42] reported that different flavor arises from different proteins, depending on the heat treatment and hydrolysis of the protein hydrolysates. Similarly, this study showed a difference in flavor between WMP and raw meat material, as they are different proteins.

\section{CONCLUSION}

In this study crude protein, crude fat, and crude ash contents of a 15\% WMP treated sample was significantly higher than the control sample $(p<0.05)$. In TPA, the hardness, chewiness, and gumminess of WMP containing samples were significantly higher than the control sample $(p<0.05)$. The sarcoplasmic and myofibrillar proteins of the 15\% WMP-treated sample was significantly higher than the control sample $(p<0.05)$. The cooking yield of WMP-treated samples was significantly higher than the control sample $(p<0.05)$. From the results of microphotographs and SDS-PAGE, WMP was effective at increasing the cooking yield and protein solubility. Thus, less than 15\% WMP can be used as heterologous protein for developing protein enriched meat product.

\section{REFERENCES}

1. Kim HK, Lee HT, Kim JH, Lee SS. Analysis of microbiological contamination in ready-to-eat foods. J Food Hyg Saf. 2008;23:285-90.

2. Heo EJ, Shin HJ, Moon JS, Park HJ, Kim YJ, Kim JH, et al. Construction of standard curve for quantitative detection of Listeria monocytogenes in ready-to-eat sausages by real-time PCR method. Korea J Vet Publ Health. 2010;34:279-84. 
3. Kim JW, Park SY. The perception and consumption pattern of broiler chicken in Korea. Korean J Poult Sci. 2001;28:193-205.

4. Organisation for Economic Cooperation and Development (OECD), Food and Agriculture Organization (FAO). OECD-FAO agricultural outlook 2019-2028: meat and dairy products. Paris: OECD; 2019.

5. Naveena BM, Sen AR, Vaithiyanathan S, Babji Y, Kondaiah N. Comparative efficacy of pomegranate juice, pomegranate rind powder extract and BHT as antioxidants in cooked chicken patties. Meat Sci. 2008;80:1304-8.

6. Kang KM, Kim GW, Kim HY. Effects of Zanthoxylum schinifolium powder on the quality properties of chicken breast emulsion-type sausages. Ann Anim Res Sci. 2020;31:13-20. https://doi.org/10.12718/AARS.2020.31.1.13

7. Ahhmed AM, Kawahara S, Ohta K, Nakade K, Soeda T, Muguruma M. Differentiation in improvements of gel strength in chicken and beef sausages induced by transglutaminase. Meat Sci. 2007;76:455-62. https://doi.org/10.1016/j.meatsci.2007.01.002

8. Lee CW, Kim TK, Hwang KE, Kim HW, Kim YB, Kim CJ, et al. Combined effects of wheat sprout and isolated soy protein on quality properties of breakfast sausage. Korean J Food Sci Anim Resour. 2017;37:52-61. https://doi.org/10.5851/kosfa.2017.37.1.52

9. Kim GY, Kim SH, Kim WS, Kim CH, Nam MS, Mun YI, Bae IH, Oh SJ, Yoon SS, Lee SW, Lee WJ, Jeon WM, Ha WK. Milk processing technology. Seoul: Yu han Mun hwwa sa; 2011.

10. Kamizake NKK, Gonçalves MM, Zaia CTBV, Zaia DAM. Determination of total proteins in cow milk powder samples: a comparative study between the Kjeldahl method and spectrophotometric methods. J Food Compos Anal. 2003;16:507-16. https://doi.org/10.1016/S08891575(03)00004-8

11. Kim JH, Kim YH, Baick SC, Lee YG, Yu JH. Studies on the manufacture of frozen yoghurt made with different mixing ratio of raw milk and whole, skim milk powder. Korean J Dairy Sci. 1993;15:128-34.

12. Jo AR, Noh HW, Kim KS, Chung KH, Jeon WM. The development of imitated cheese using whole milk powder and fermented milk. Korean J Food Sci Anim Resour. 2010;30:102-9. https://doi.org/10.5851/kosfa.2010.30.1.102

13. Back SY, Kim SS, Lim SD, Do JR. Quality characteristics of soup with whole milk powder and Pleurotus eryngii powder. J Dairy Sci Biotechnol. 2017;35:113-9. https://doi.org/10.22424/ jmsb.2017.35.2.113

14. Association of Official Analytical Chemists [AOAC] International. Official methods of analysis. 16th ed. Arlington, VA: AOAC International; 1995.

15. Lee SH, Choe J, Kim JC, Kim HY. Effect of seawater on the technological properties of chicken emulsion sausage in a model system. Food Sci Anim Res. 2020;40:377-87. https://doi. org/10.5851/kosfa.2020.e18

16. Kim AJ, Lee JE, Lee JM, Lee S, Min SG. The study on the sensory evaluation and physicochemical properties of sausage manufactured with different mixture ratios of chicken and pork meat. Korean J Food Sci Anim Resour. 2000;20:173-80.

17. Akhtar S, Zahoor T, Hashmi AM. Physico-chemical changes in UHT treated and whole milk powder during storage at ambient temperature.J Res Sci. 2003;14:97-102.

18. Eswarapragada NM, Reddy PM, Prabhakar K. Quality of low fat pork sausage containing milk-co-precipitate. J Food Sci Technol. 2010;47:571-3. https://doi.org/10.1007/s13197-0100086-1

19. Koc AB, Heinemann PH, Ziegler GR. Optimization of whole milk powder processing variables with neural networks and genetic algorithms. Food Bioprod Process. 2007;85:336-43. 
https://doi.org/10.1205/fbp07074

20. Andrès S, Zaritzky N, Califano A. The effect of whey protein concentrates and hydrocolloids on the texture and colour characteristics of chicken sausages. Int J Food Sci Technol. 2006;41:954-61. https://doi.org/10.1111/j.1365-2621.2005.01152.x

21. Chang KS, Chang YI, Chun KC, Lee SG. Effects of water activity on the non-enzymatic browning reaction of dry milk. Appl Biol Chem. 1985;28:261-70.

22. Lim SD, Kim KS, Park WM, Park DJ, Kang TS. Effect of packaging conditions on the quality of whole milk powder (2). The shelf-life prediction of whole milk powder by packaging conditions. Korean J Anim Sci. 1994;36:100-7.

23. Morales FJ, Van Boekel MAJS. A study on advanced Maillard reaction in heated casein/sugar solutions: colour formation. Int Dairy J. 1998;8:907-15. https://doi.org/10.1016/S09586946(99)00014-X

24. Jeong JE, Hong YH. Properties of transglutaminase treated milk product powders. Korean J Food Sci Technol. 2005;37:345-51.

25. Hung SC, Zayas JF. Functionality of milk proteins and corn germ protein flour in comminuted meat products 1. J Food Qual. 1992;15:139-52. https://doi.org/10.1111/j.1745-4557.1992. tb00982.x

26. Abdolghafour B, Saghir A. Effect of whey protein concentrate on quality and shelf life of buffalo meat emulsion sausage. Sch J Agric Vet Sci. 2014;1:201-10.

27. Radoslav G, Danica S. Analysis of myofibrillar and sarcoplasmic proteins in pork meat by capillary gel electrophoresis. Foods Raw Mater. 2018;6:421-8. https://doi.org/10.21603/23084057-2018-2-421-428

28. Grossi A, Olsen K, Bolumar T, Rinnan Å, Øgendal LH, Orlien V. The effect of high pressure on the functional properties of pork myofibrillar proteins. Food Chem. 2016;196:1005-15. https://doi.org/10.1016/j.foodchem.2015.10.062

29. Kwon HY. Physiological function and structure of protein C. Korean J Med Technol. 1989;21:22-6.

30. Rumondor DBJ, Tinangon R, Paath J, Pujihastuti E, Ransaleleh T. Proteins profil of sausage laying chicken meat with Angkak (red rice) used as natural food material. Sci Pap Ser D Anim Sci. 2019;62:270-4.

31. Agarwal A, Pathera AK, Kaushik R, Kumar N, Dhull SB, Arora S, et al. Succinylation of milk proteins: influence on micronutrient binding and functional indices. Trends Food Sci Technol. 2020;97:254-64. https://doi.org/10.1016/j.tifs.2020.01.016

32. Choi YI. Effects of salt and phosphate on functional properties of preblended pork and microstructure of emulsion type sausage. Korean J Anim Sci. 1987;29:310-5.

33. Muguruma M, Tsuruoka K, Katayama K, Erwanto Y, Kawahara S, Yamauchi K, et al. Soybean and milk proteins modified by transglutaminase improves chicken sausage texture even at reduced levels of phosphate. Meat Sci. 2003;63:191-7. https://doi.org/10.1016/S03091740(02)00070-0

34. Zhou C, Li J, Tan S. Effect of L-lysine on the physicochemical properties of pork sausage. Food Sci Biotechnol. 2014;23:775-80.

35. Barbut S. Effects of milk powder and its components on texture, yield, and color of a lean poultry meat model system. Poultr Sci. 2010;89:1320-4. https://doi.org/10.3382/ps.2009-00506

36. Serdaroğlu M. Improving low fat meatball characteristics by adding whey powder. Meat Sci. 2006;72:155-63. https://doi.org/10.1016/j.meatsci.2005.06.012

37. Marchetti L, Andrés SC, Califano AN. Low-fat meat sausages with fish oil: optimization of milk proteins and carrageenan contents using response surface methodology. Meat Sci. 
2014;96:1297-303. https://doi.org/10.1016/j.meatsci.2013.11.004

38. Choe J, Kim JH, Kim BK, Park HB, Kim GW, Kim HY. Physicochemical properties of chicken thigh meat sausage manufactured with red yeast rice powder. Korean J Poultr Sci. 2019;46:11-5. https://doi.org/10.5536/KJPS.2019.46.1.11

39. Eklöv T, Johansson G, Winquist F, Lundström I. Monitoring sausage fermentation using an electronic nose. J Sci Food Agric. 1998;76:525-32. https://doi.org/10.1002/(SICI)10970010(199804)76:4<525::AID-JSFA983>3.0.CO;2-A

40. Kühn J, Considine T, Singh H. Interactions of milk proteins and volatile flavor compounds: implications in the development of protein foods. J Food Sci. 2006;71:R72-82. https://doi. org/10.1111/j.1750-3841.2006.00051.x

41. Xiao Z, Yu D, Niu Y, Chen F, Song S, Zhu J, et al. Characterization of aroma compounds of Chinese famous liquors by gas chromatography-mass spectrometry and flash GC electronic-nose.J Chromatogr B. 2014;945:92-100. https://doi.org/10.1016/j.jchromb.2013.11.032

42. Christiansen KF, Krekling T, Kohler A, Vegarud G, Langsrud T, Egelandsdal B. Microstructure and sensory properties of high pressure processed dressings stabilized by different whey proteins. Food Hydrocoll. 2006;20:650-62. https://doi.org/10.1016/j.foodhyd.2005.06.004 